\title{
Divergent roles for thyroid hormone receptor $\beta$ isoforms in the endocrine axis and auditory system
}

\author{
E. Dale Abel, ${ }^{1}$ Mary-Ellen Boers,${ }^{1}$ Carmen Pazos-Moura, ${ }^{1,2}$ Egberto Moura, ${ }^{1,3}$ \\ Helen Kaulbach, ${ }^{1}$ Marjorie Zakaria, ${ }^{4}$ Bradford Lowell, ${ }^{5}$ Sally Radovick, ${ }^{4}$ \\ M. Charles Liberman, ${ }^{6}$ and Fredric Wondisford ${ }^{1}$
}

${ }^{1}$ Thyroid Unit, Department of Medicine, Beth Israel Deaconess Medical Center and Harvard Medical School, Boston, Massachusetts 02215, USA

${ }^{2}$ Laboratorio de Fisiologia Endocrina, Instituto de Biofisica Carlos Chagas Filho, Universidade Federal do Rio de Janeiro, Ilha do Fundao, 21000-000 Rio de Janeiro, Brazil

${ }^{3}$ Departamento de Ciencias Fisiologicas, Instituto de Biologia, Universidade do Estado do Rio de Janeiro, 20550-030

Rio de Janeiro, Brazil

${ }^{4}$ Division of Endocrinology, Children's Hospital, Harvard Medical School, Boston, Massachusetts 02115, USA

${ }^{5}$ Division of Endocrinology, Department of Medicine, Beth Israel Deaconess Medical Center and Harvard Medical School,

Boston, Massachusetts 02115, USA

6Eaton-Peabody Laboratory, Massachusetts Eye and Ear Infirmary, Boston, Massachusetts 02114, USA

Address correspondence to: Fredric E. Wondisford, Thyroid Unit, Department of Medicine, Beth Israel Deaconess

Medical Center, 330 Brookline Avenue, Boston, Massachusetts 02215, USA. Phone: (617) 667-2151;

Fax: (617) 667-2927; E-mail: fwondisf@caregroup.harvard.edu.

Received for publication January 28, 1999, and accepted in revised form June 21, 1999.

Thyroid hormone receptors (TRs) modulate various physiological functions in many organ systems. The TR $\alpha$ and TR $\beta$ isoforms are products of 2 distinct genes, and the $\beta 1$ and $\beta 2$ isoforms are splice variants of the same gene. Whereas TR $\alpha 1$ and TR $\beta 1$ are widely expressed, expression of the TR $\beta 2$ isoform is mainly limited to the pituitary, triiodothyronine-responsive TRH neurons, the developing inner ear, and the retina. Mice with targeted disruption of the entire TR $\beta$ locus (TR $\beta$-null) exhibit elevated thyroid hormone levels as a result of abnormal central regulation of thyrotropin, and also develop profound hearing loss. To clarify the contribution of the TR $\beta 2$ isoform to the function of the endocrine and auditory systems in vivo, we have generated mice with targeted disruption of the TR $\beta 2$ isoform. $\operatorname{TR} \beta 2$-null mice have preserved expression of the TR $\alpha$ and TR $\beta 1$ isoforms. They develop a similar degree of central resistance to thyroid hormone as TR $\beta$-null mice, indicating the important role of TR $\beta 2$ in the regulation of the hypothalamic-pituitary-thyroid axis. Growth hormone gene expression is marginally reduced. In contrast, TR $\beta 2$-null mice exhibit no evidence of hearing impairment, indicating that TR $\beta 1$ and TR $\beta 2$ subserve divergent roles in the regulation of auditory function.

J. Clin. Invest. 104:291-300 (1999).

\section{Introduction}

Thyroid hormone (triiodothyronine $\left[\mathrm{T}_{3}\right]$ ) mediates its pleiotropic effects by binding to thyroid hormone receptors (TRs), which are nuclear transcription factors regulating gene expression by binding to specific thyroid hormone response elements (TREs) on the promoters of thyroid hormone-responsive genes (1). There are $3 \mathrm{~T}_{3}$-binding isoforms of the TR: TR $\alpha 1$, TR $\beta 1$, and TR $\beta 2$ (1-4). The TR $\alpha$ and TR $\beta$ isoforms are the products of distinct genes residing on separate chromosomes (1). The 2 isoforms of TR $\beta$ are derived by alternative exon use within the TR $\beta$ locus (5-7). The receptors are entirely homologous, with the exception of distinct $\mathrm{NH}_{2}$-termini. The TR $\beta 1$ isoform is widely expressed and is particularly abundant in the liver and kidney; but it is also present in the pituitary, the hypothalamus, and the developing nervous system (1).

In contrast, the expression of TR $\beta 2$ is relatively restricted and is most highly expressed in the pituitary (4). Significant expression has also been described in the hypothalamus $(8,9)$ and the developing ear $(10)$. Very low level expression of TR $\beta 2$ has been described in peripheral tissues (11), but it is unknown whether these low levels subserve significant functions in those tissues. TR $\beta 2$ expression is highly regulated by $\mathrm{T}_{3}(4,12)$ and thyrotropin-releasing hormone (TRH) (13). In the pituitary, TR $\beta 2$ mRNA is more abundant than TR $\beta 1$ mRNA (4). Furthermore, selective depletion of TR $\beta 2$ mRNA in a pituitary-derived cell line (GH3) was associated with marked inhibition of $\mathrm{T}_{3}$ responsiveness of the growth hormone (GH) gene (14). Thus, the differential expression of the TR $\beta$ isoforms and the predominant expression in the pituitary and hypothalamus raise the possibility that TR $\beta 2$ may play an important role in the central regulation of the hypothalamic-pituitary-thyroid axis.

Transfection experiments have revealed differential properties of TR $\beta 1$ and TR $\beta 2$ in vitro. For example, TR $\beta 2$ causes ligand-independent activation of the GH promoter in the presence of retinoid $\mathrm{X}$ receptor (RXR), 
a
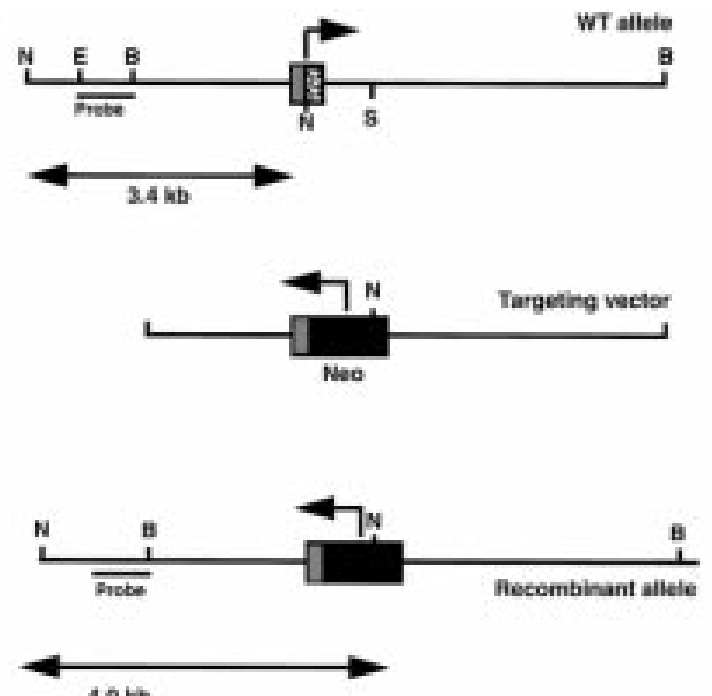

$4.0 \mathrm{~kb}$

b

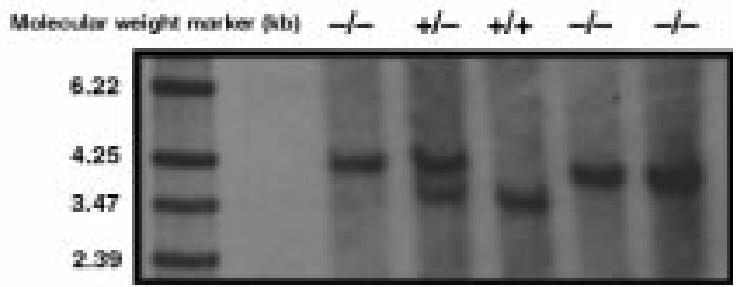

Figure 1

Targeted disruption of the TR $\beta 2$ exon. (a) Schematic representation of the TR $\beta 2$ exon and flanking DNA sequence. The targeting vector was generated by deleting a 1-kb Ncol-Sacl fragment encompassing the entire coding exon of the TR $\beta 2 \mathrm{NH}_{2}$-terminus and the adjacent intron, and by inserting the neomycin resistance gene under the influence of the phosphoglycerate kinase promoter. Homologous integration of the targeting vector was confirmed by Southern blot of genomic DNA digested with $N c o l$ and probed with an $\alpha$ - ${ }^{32}$ P-labeled, 700-bp EcoRI-BamHI DNA fragment that is immediately upstream of the start of the targeting vector. The values $3.4 \mathrm{~kb}$ and $4.0 \mathrm{~kb}$ represent the expected sizes of the hybridized band in the WT and targeted alleles, respectively. B, BamHI; E, EcoRI; N, Ncol; S, Sacl. (b) Representative Southern blot, demonstrating the targeted and WT alleles in $\mathrm{KO}(-/-)$, heterozygous $(+/-)$, and $\mathrm{WT}(+/+)$ mice.

whereas TR $\beta 1$ mediates ligand-independent repression under these circumstances (15). On negative TREs, TR $\beta 2$ is a more potent mediator of ligand-independent activation than TR $\beta 1$ or TR $\alpha 1(16,17)$. This property of TR $\beta 2$ has been mapped to amino acid residues $89-116$ in its unique $\mathrm{NH}_{2}$-terminus and can be transferred to TR $\alpha$ by exchanging the TR $\alpha \mathrm{NH}_{2}$-terminus with that of TR $\beta 2$ (18). RXR modulates the ability of TR $\beta 1$ and TR $\alpha 1$ to mediate negative regulation of the TRH gene in the presence or absence of its ligand, 9-cis retinoic acid. However RXR has no such effect on TR $\beta 2$ (19). Our laboratory has also demonstrated recently that whereas the transcriptional activity of TR $\beta 1$ and TR $\alpha 1$ can be modulated by interaction with the nuclear corepressor ( $\mathrm{N}-\mathrm{CoR}), \mathrm{TR} \beta 2$ does not possess this property (20). Mutations that cause selective pituitary resistance to thyroid hormone in humans selectively impair the function of TR $\beta 2$ but not TR $\beta 1$ (17). Hence, in tissues where both TR isoforms are expressed, there is ample in vitro evidence that these receptors may mediate distinct effects on gene transcription in the presence and absence of thyroid hormone.

Mice with targeted disruption of the TR $\beta$ locus (Tr $\beta$ null) (21), the TR $\alpha$ locus (22), and the TR $\alpha 1$ gene product (23) have been reported, and they have shed some light on the relative roles of each TR isoform in the regulation of the hypothalamic-pituitary-thyroid axis. TR $\beta$-null mice exhibit elevated thyroid hormone concentrations and inappropriately elevated concentrations of thyrotropin (TSH) (21). Furthermore, in response to the administration of exogenous thyroid hormone, there is partial suppression of TSH, implying profound resistance to thyroid hormone (24). Hence, TR $\beta$ plays a key role in the central regulation of TSH. TR $\beta$-null mice are also deaf, implying an important role for this isoform in the regulation of hearing (25). Given the coexistence of both TR $\beta$ isoforms in the pituitary and the developing cochlea, it is unclear if the hormonal abnormalities and the defective hearing are due to loss of TR $\beta 1$, TR $\beta 2$, or both. In contrast, selective ablation of the TR $\alpha$ isoform results in small declines in thyroid hormone concentrations, consistent with central hypothyroidism $(22,23)$.

To test the hypothesis that TR $\beta 2$ - by virtue of its restricted expression - is the key TR isoform responsible for the regulation of TSH, and to explore the possibility that TR $\beta 1$ and TR $\beta 2$ subserve distinct roles in the regulation of the auditory system, we generated transgenic mice with targeted disruption of the $\beta 2$ isoform of the TR. These mice develop elevated concentrations of thyroid hormone and impaired suppression of thyroid hormone in response to the administration of exogenous $\mathrm{T}_{3}$. Furthermore, the absence of $\mathrm{TR} \beta 2$ profoundly impairs the activation of the TSH $\beta$ gene in vivo in the absence of thyroid hormone. Thus, the $\beta 2$ isoform of the TR plays a critical role in the regulation of the hypothalamic-pituitary-thyroid axis. In contrast to mice that lack both TR $\beta$ isoforms, mice with an absence of TR $\beta 2$ do not exhibit hearing deficits.

\section{Methods}

Targeting vector. PCR primers (5'-AGG TGC TAC TCT GAA GTG AG-3' and 5'-ATA TGC TGC TAC TGG GCA CA-3') that correspond to specific sequences within the TR $\beta 2$-specific $\mathrm{NH}_{2}$-terminal coding exon were used to amplify the 129 embryonic stem (ES) cell genomic DNA coding a probe that was used to used to screen a 129 P1 genomic DNA library (Genome Systems Inc., St. Louis, Missouri, USA). A 70-kb fragment of the TR $\beta 2$ genomic locus was obtained, and an 8-kb $B a m H I$ fragment containing the TR $\beta 2$-specific exon was subcloned as 2 contiguous Bam HI-EcoRI fragments (TR $\beta 2 \mathrm{~L}$ and TR $\beta 2 \mathrm{R}$, respectively). TR $\beta 2 \mathrm{~L}$ contained the TR $\beta 2$-specific exon, the presence of which was confirmed by sequencing. A 1-kb fragment extending from an NcoI site $77 \mathrm{bp}$ upstream of the transcription start 


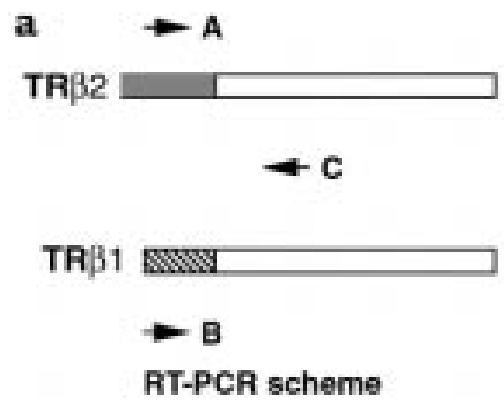

b

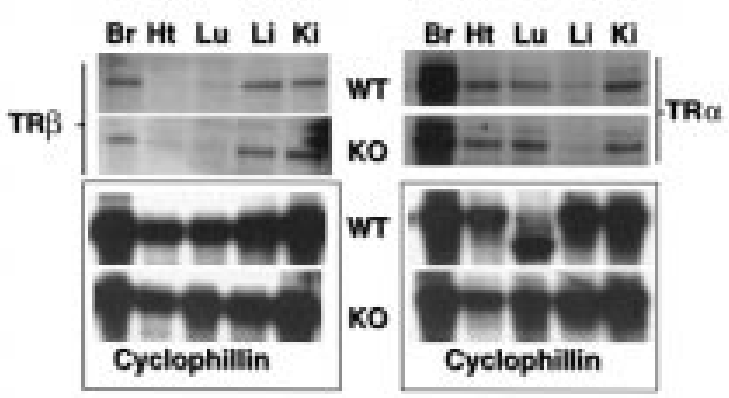

Figure 2

TR isoform expression. (a) RT-PCR of pituitary RNA (pooled from $6 \mathrm{KO}$ and 6 WT mice), demonstrating the absence of the TR $\beta 2$ transcript in KO mice. The $5^{\prime}$ PCR primers used were specific for TR $\beta 2$ and TR $\beta 1$ (denoted $A$ and $B$, respectively). The $3^{\prime}$ primer (denoted C) was common to both TR isoforms. $L$, molecular weight ladder; WT, wild-type; KO, knockout; $\varnothing$, no added RNA. (b) RNase protection assays examining $\operatorname{TR} \beta$ and $\operatorname{TR} \alpha$ expression in multiple tissues of WT and $\mathrm{KO}$ mice. $\mathrm{Br}$, brain; $\mathrm{Ht}$, heart; Lu, lung; Li, liver; Ki, kidney. site to a SacI site approximately $600 \mathrm{bp}$ downstream of the end of the exon was excised, and a cDNA cassette containing the neomycin resistance gene under the influence of the phosphoglycerate kinase promoter was ligated into this space (Figure 1a). This maneuver thus eliminated the transcription start site, the entire TR $\beta 2$ specific exon, its splice donor acceptor site, and approximately $600 \mathrm{bp}$ of the adjacent intron. TR $\beta 2 \mathrm{~L}+\mathrm{Neo}$ was then subcloned into a vector (pBluescript; Stratagene, La Jolla, California, USA) that contained TR $\beta 2$ R, thereby adding an additional $4.5 \mathrm{~kb}$ of homologous intronic DNA downstream of TR $\beta 2 \mathrm{~L}+\mathrm{Neo}$. The vector was linearized with $X h o \mathrm{I}$ before electroporation into J1 ES cells $(26,27)$, and the cells were propagated in media containing G418.

ES cell selection and generation of mutant mice. A 700-bp EcoRI-BamHI fragment immediately $5^{\prime}$ of the start of the targeting vector was obtained from a plasmid (gift of W.W. Wood, Health Sciences Center, University of Colorado, Denver, Colorado, USA) that contained 4.4 $\mathrm{kb}$ of the mouse TR $\beta 2$-specific locus as an EcoRI fragment. With this as a probe, an NcoI digest of genomic DNA reveals a 3.4-kb band for the endogenous allele and a 4.0-kb band for the targeted allele (Figure 1, a and b). Next, 211 G418-resistant colonies were screened. After expansion of these clones, genomic DNA was extracted using proteinase $\mathrm{K}$ digestion, high-salt precipitation, and DNA purification by ethanol precipitation. The DNA was digested with NcoI, and Southern blotting was performed after agarose gel electrophoresis. Homologous integration of the targeting construct was detected in 2 clones (76A and 107B), which were subsequently injected into 3-day-old blastocysts of the C57Bl 6 strain and then transferred into the uteri of pseudopregnant foster mothers. Chimeric offspring were successfully derived from clone 107B. Agouti off- spring from these chimera were genotyped by Southern blotting of genomic DNA isolated from tail clippings from 14- to 21-day-old animals. The DNA was extracted by overnight digestion with proteinase $\mathrm{K}$ and SDS, followed by high-salt precipitation, phenol chloroform extraction, and ethanol precipitation. DNA $(10 \mu \mathrm{g})$ was digested with $\mathrm{NcoI}$ and then screened as described above for the ES cells. Offspring of the chimeric mice were either homozygous for the TR $\beta$ wild-type (WT) allele or heterozygous for the targeted allele. TR $\beta 2$-null (knockout [KO]) mice were then generated by crossing heterozygous mice. For all studies, the control mice used were either littermates of the TR $\beta 2$-null mice or offspring of WT littermates. Hence, all comparisons were made in mice of the same genetic background.

RNA analysis. Pituitary RNA was extracted from pooled pituitaries (5-8 animals) using guanidinium thiocyanate, selective precipitation, and isopycnic centrifugation with lithium chloride and cesium trifluoroacetate (Amersham Pharmacia Biotech, Piscataway, New Jersey, USA). For other tissues, RNA was extracted from tissue homogenates into a phenol and guanidinium thiocyanate solution (RNA Stat-60 reagent; TelTest Inc., Friendswood, Texas, USA) and then recovered by isopropanol precipitation. The presence of the TR $\beta 1$ transcript, and the presence or absence of the TR $\beta 2$ transcript, in pituitary RNA was established by performing RT-PCR on DNaseI-treated samples using the following 3 primers: TR $\beta 2$-specific $5^{\prime}$-ATG AAC TAC TGT ATG CCA GAG GTA-3', denoted primer A; TR $\beta 1$ specific 5'-GCC TGG GAC AAG CAG AAG CCC CGT$3^{\prime}$, denoted primer B; and a $3^{\prime}$ primer common to TR $\beta 1$ and TR $\beta 2: 5^{\prime}$-GTC TAA ATA GCT GGG CAT ATA CC$3^{\prime}$, denoted primer C (Figure 2a). PCR products were resolved on a 3\% agarose gel. TR $\alpha$ and TR $\beta$ gene expression was assessed in the brain, heart, lung, liver, and 


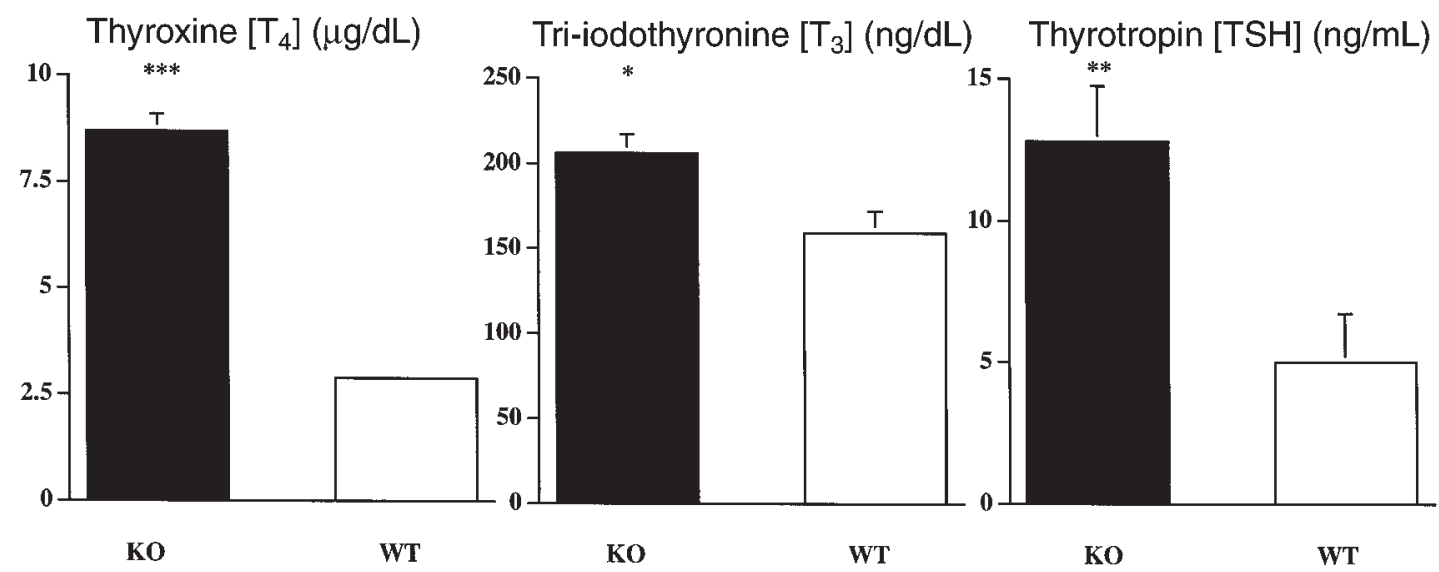

Figure 3

Basal serum concentrations of $\mathrm{T}_{4}, \mathrm{~T}_{3}$, and TSH in $\mathrm{KO}$ and WT mice. Numbers of animals are $13 \mathrm{KO}$ and $18 \mathrm{WT}$ for $\mathrm{T}_{4}$ assays, $18 \mathrm{KO}$ and 14 WT for TSH assays, and $8 \mathrm{KO}$ and $8 \mathrm{WT}$ for $\mathrm{T}_{3}$ assays. ${ }^{*}{ }^{*} P<0.0001,{ }^{*} P<0.01$, and ${ }^{*} P<0.02 \mathrm{KO}$ vs. WT.

kidney by RNase protection. Next, $20 \mu \mathrm{g}$ of total RNA from each of these tissues was hybridized with $\alpha$ ${ }^{32} \mathrm{P}$-labeled cRNA probes corresponding to sequences specific for the mouse TR $\alpha$ and TR $\beta$, and processed using the Ribonuclease Protection Assay Kit (Ambion Inc., Austin, Texas, USA). The RNase-digested products were resolved on nondenaturing polyacrylamide gels. The TR $\alpha$ riboprobe was generated from a plasmid containing a 155-bp fragment of $\mathrm{NH}_{2}$-terminus of mouse TR $\alpha 1$. The fragment was obtained by RT-PCR of mouse brain total RNA using the primers 5 -GTG AAT GGA ACA GAA GCC AAG-3' and 5'-CGT CTT TGT CCA GGT AAC TAG-3', and was subcloned into the vector PGEM-T (Promega Corp., Madison, Wisconsin, USA). After verifying the sequence, the plasmid was linearized with $N c o I$, and the cRNA was transcribed with SP6 RNA polymerase. The TR $\beta$ riboprobe was derived from a 500-bp BamHI-XbaI fragment of the TR $\beta$ genomic locus subcloned into PGEM-7 (Promega Corp.), which contained exon 6 and the flanking intronic sequence. The plasmid was linearized with BamHI, and the cRNA was transcribed with T7 RNA polymerase. A cyclophillin riboprobe (Ambion Inc.) was used to control for loading. TSH $\beta$ and GH gene expression were assayed in pituitary total RNA by Northern blotting. In studies of TSH $\beta$ gene regulation, $5,2.5$, 1.25 , and $0.625 \mu \mathrm{g}$ of RNA obtained from hypothyroid mice were prepared by serial dilution. In studies of euthyroid and hyperthyroid mice, $15 \mu \mathrm{g}$ of RNA was used. Samples were resolved on a $1.2 \%$ formaldehyde agarose gel, transferred to a nylon membrane, and hybridized to the entire cDNA of the $\beta$ subunit of murine TSH (labeled with $\left.\left[\alpha-{ }^{32} \mathrm{P}\right] \mathrm{dCTP}\right)$ under highstringency conditions. For the GH experiments, $5 \mu \mathrm{g}$ of RNA was hybridized under high-stringency conditions to an $\alpha-{ }^{32} \mathrm{P}-$-labeled cDNA probe corresponding to 790 bp of the rat GH gene.

$T_{3}$ suppression and hypothyroidism. Blood was obtained for total thyroxine $\left(\mathrm{T}_{4}\right)$ and TSH from the tail vein. Experimental hypothyroidism was induced by admin- istering $150 \mu \mathrm{Ci}$ of ${ }^{131} \mathrm{I}$ by intraperitoneal injection to mice who had been placed on a low-iodine diet (Harland Teklad Laboratory, Madison, Wisconsin, USA) for 8 days. Experiments on hypothyroid animals were performed 3 weeks after the administration of ${ }^{131} \mathrm{I}$, as all mice develop undetectable $T_{4}$ concentrations by the third week. Suppression of pituitary TSH production was attempted by daily intraperitoneal injections of $T_{3}$ $(1 \mu \mathrm{g} / \mathrm{mL})$ in buffered HEPES for 3 weeks at doses of $0.2 \mu \mathrm{g} / 100 \mathrm{~g}$ body weight during the first week, 0.5 $\mu \mathrm{g} / 100 \mathrm{~g}$ body weight during the second week, and 1.0 $\mu \mathrm{g} / 100 \mathrm{~g}$ body weight during the third week. Comparisons were made between $\mathrm{KO}$ mice and age-matched, WT controls of the same genetic background. Serum samples were obtained and pituitaries harvested on the day of the final $\mathrm{T}_{3}$ dose. For studies of the regulation of GH gene expression by thyroid hormone, $\mathrm{KO}$ and control mice were treated for 3 days with $10 \mu \mathrm{g}$ of $\mathrm{T}_{3}$ per day by intraperitoneal injection, after which pituitaries were harvested for RNA. All aspects of animal care and experimentation performed in this study were approved by the Institutional Animal Care and Use Committee of the Beth Israel Deaconess Medical Center. Animals were maintained on a 12-hour light/12hour dark schedule (light on at 0600 hours) and fed laboratory chow and water ad libitum.

Hormone assays. Total $\mathrm{T}_{4}$ levels were measured in 10$\mu \mathrm{L}$ serum samples in duplicate determinations by a mouse-specific RIA (ImmuChem-coated tube, $\mathrm{T}_{4}{ }^{125} \mathrm{I}$ RIA Kit; ICN Pharmaceuticals, Costa Mesa, California, USA). Total $T_{3}$ was measured in $100-\mu \mathrm{L}$ serum samples by RIA (ImmuChem-coated tube $\mathrm{T}_{3}{ }^{125}$ I RIA Kit; ICN Pharmaceuticals). TSH was measured in $50-\mu \mathrm{L}$ serum samples in triplicate determinations by a specific mouse TSH RIA (Anilytics, Gaithersburg, Maryland, USA), reference preparation (AFP51718mp), a mouse TSH antiserum (AFP98991), and rat TSH antigen for radioiodination (NIDDK-rTSH-I-9) (all obtained from A.F. Parlow, Harbor University of California-Los Angeles Medical Center, Torrance, California, USA). 
Analysis of hearing. To record auditory brainstem responses (ABRs), mice were anesthetized with xylazine $(50 \mathrm{mg} / \mathrm{kg}$ intraperitoneally $)$ and ketamine (100 mg/kg intraperitoneally). The external auditory canal was slit to provide a direct view of the eardrum, and a closed, calibrated acoustic system was positioned near the drum. Needle electrodes were inserted (vertex and pinna, with a ground near the tail), and responses were amplified $(\times 10,000)$, filtered $(0.3-3.0$ $\mathrm{kHz}$ band pass), digitized, and averaged (1,024 responses, with equal numbers of opposite stimulus polarity) with custom software, including artifact rejection to eliminate large cardiac potentials. Stimuli were 5 -millisecond tone pips (0.5 millisecond rise-fall, with $\cos ^{2}$ shaping) delivered at 40 per second. At each test frequency, sound pressure was varied in 5-dB steps from 5-dB sound pressure levels (SPLs) up to at least $20 \mathrm{~dB}$ above threshold, as defined by visual inspection of the response waveforms.

Statistical analysis. Differences were assessed by 1-tailed Student's $t$ test (2-sample unequal variance).

\section{Results}

Generation of mice lacking TR $\beta 2$. The targeting vector (Figure 1a), in which the TR $\beta 2$-specific exon was replaced by the neomycin resistance gene driven by the phosphoglycerate kinase promoter, was electroporated into J1 ES cells $(26,27)$. The targeted allele was readily detected by Southern blot analysis (Figure 1b). A total of 211 ES cell colonies were screened, and homologous recombination occurred in 2 clones (76A and 107B). After expansion, these clones were injected into
C57B16 blastocysts. Only ES cells from clone 107B successfully passed through the germ line of chimeric mice. Initial breeding yielded 115 mice. If the inheritance were mendelian, the expected frequency of WT, heterozygous, and homozygous (KO) mice would be 28,57 , and 27 respectively. We observed 24 WT, 62 heterozygous, and 29 homozygous mice, which is consistent with the expected mendelian frequency of inheritance. Hence, deletion of the TR $\beta 2$ exon was not associated with impaired embryonic survival. To demonstrate that our targeting strategy resulted in the selective loss of TR $\beta 2$ expression, we performed RTPCR using isoform-specific $5^{\prime}$ primers and a common $3^{\prime}$ primer (Figure $2 \mathrm{a}$ ). We were able to amplify the TR $\beta 1$, but not the TR $\beta 2$, transcript from pituitary RNA obtained from homozygous mice, indicating that our targeting strategy successfully inactivated TR $\beta 2$ expression. In WT mice, both transcripts were amplified. The RT-PCR fragments were subcloned, and sequence analysis verified that the 2 transcripts obtained in WT mice corresponded to TR $\beta 1$ and $\mathrm{TR} \beta 2$, respectively, whereas the transcript in the KO mice was TR $\beta 1$. Although not quantitative, the RTPCR analysis suggests that the levels of TR $\beta 1$ expression in the pituitaries of WT and KO mice were similar. TR $\alpha 1$-specific primers were also used to demonstrate that $\mathrm{TR} \alpha$ expression was preserved in the pituitaries of TR $\beta 2$-null mice (data not shown).

Impact on TR $\alpha$ and TR $\beta$ expression. To assess more carefully the impact of our targeting strategy on TR $\beta$ and TR $\alpha$ gene expression, RNase protection assays were performed on total RNA obtained from the brains, a

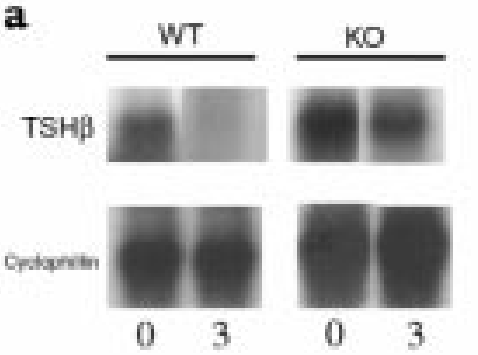

c

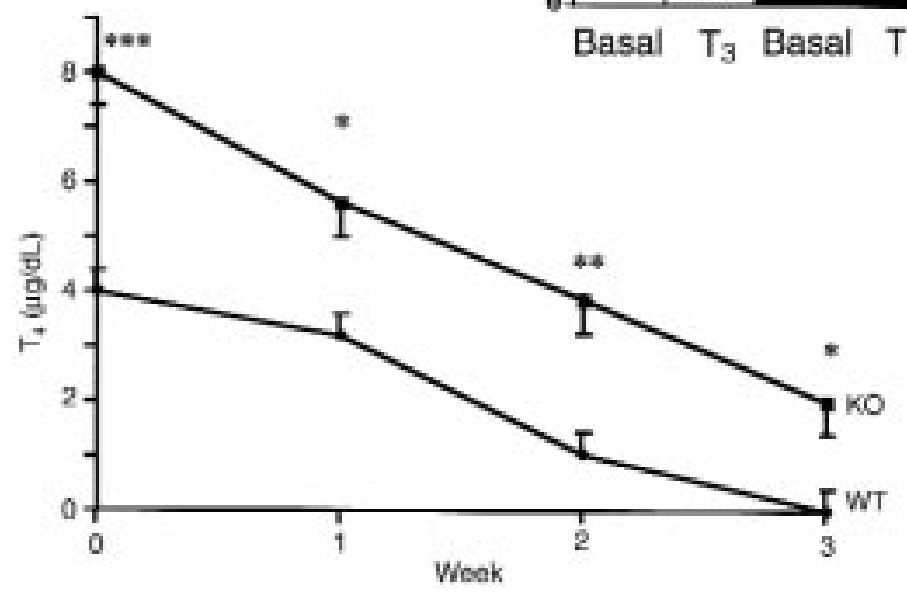

b

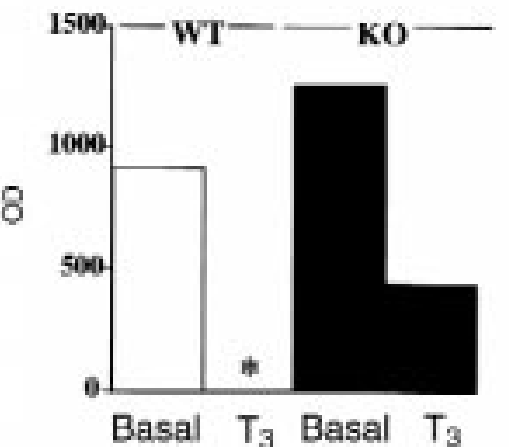

Figure 4

TSH and $\mathrm{T}_{4}$ response to $\mathrm{T}_{3}$ administration. (a) Northern blots of pituitary RNA from WT and $\mathrm{KO}$ mice at baseline (0) and after 3 weeks of $\mathrm{T}_{3}$ administration (3). Blots were probed for TSH $\beta$ and cyclophillin. Note the complete suppression of TSH $\beta$ message by $\mathrm{T}_{3}$ in WT mice, and the partial suppression in KO mice. (b) Densitometric analysis of TSH $\beta$ Northern blots corrected for loading with cyclophillin densities. ${ }^{*}$ WT TSH $\beta$ mRNA after $T_{3}$ suppression was not detectable above background counts. (c) Serum $\mathrm{T}_{4}$ measured at weekly intervals in $\mathrm{KO}(n=8)$ and WT $(n=6)$ mice. Mice were injected daily with $\mathrm{T}_{3}$ for the entire 3-week period. ${ }^{*} P<0.02, * * P<0.01, * * * P<0.001$ vs. WT. 

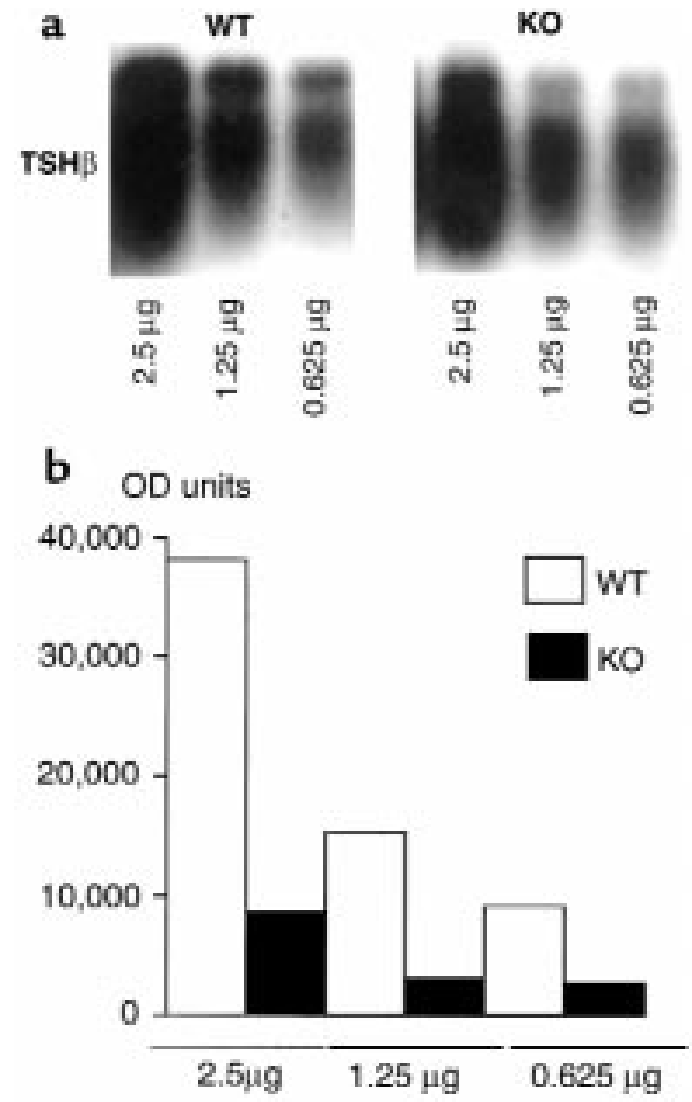

Figure 5

TSH response to hypothyroidism. (a) Northern blot of total RNA obtained from pooled pituitaries ( $n=5$ for WT and KO), demonstrating TSH $\beta$ mRNA responses in hypothyroid WT and KO mice. Amount of RNA loaded in each lane (in micrograms) is shown. (b) Densitometry of TSH $\beta$ mRNA abundance corrected for loading by hybridizing the same membranes with a cDNA for actin. Note the reduced response to hypothyroidism in KO vs. WT mice.

heart, lungs, livers, and kidneys of WT and KO mice. The TR $\alpha$ riboprobe was generated from a plasmid containing a 155-bp fragment of the $\mathrm{NH}_{2}$-terminus of mouse TR $\alpha 1$. The TR $\beta$ riboprobe was derived from a 500-bp BamHI-XbaI fragment of the TR $\beta$ genomic locus that contained exon 6 and the flanking intronic sequence. In both WT and $\mathrm{KO}$ mice, $\mathrm{TR} \alpha$ expression was highest in brain, but also significant in the heart and kidney. In contrast, TR $\beta$ expression was most prominent in the liver, kidney, and brain. The pattern of TR expression was qualitatively similar between the WT and the KO mice (Figure $2 \mathrm{~b}$ ).

Effect of loss of TR $\beta 2$ on basal thyroid hormone concentrations. Absence of TR $\beta 2$ was associated with impairment in the regulation of TSH. Basal $\mathrm{T}_{4}$ concentrations were 2- to 3-fold higher in $\mathrm{KO}$ mice compared with agematched littermate controls $(8.7 \pm 0.4 \mu \mathrm{g} / \mathrm{dL})$ versus WT mice $(2.9 \pm 0.1 \mu \mathrm{g} / \mathrm{dL})(P<0.0001)$. $\mathrm{T}_{3}$ concentrations were increased by $40 \%(206.3 \pm 11.0 \mathrm{ng} / \mathrm{dL})$ versus WT mice $(159.5 \pm 12.9 \mathrm{ng} / \mathrm{dL})(P<0.02$; Figure 3$)$. The elevated thyroid hormone concentrations were associated with inappropriate TSH production. TSH concentra- tions were 2.5 -fold higher in $\mathrm{KO}$ mice $(12.8 \pm 1.9$ $\mathrm{ng} / \mathrm{mL})$ versus WT mice $(5.0 \pm 1.7 \mathrm{ng} / \mathrm{mL})(P<0.005)$, which is compatible with resistance at the level of the pituitary (Figure 3). At the level of gene expression, TR $\beta 2 \mathrm{KO}$ mice exhibited increased levels of TSH $\beta$ mRNA (Figure 4a). There was no discernible effect, however, on $\alpha$-subunit gene expression (data not shown).

Impact on pituitary responsiveness to thyroid hormone. To confirm the presence of central resistance to thyroid hormone, $\mathrm{KO}$ and control mice were treated for 3 weeks with pharmacological doses of $\mathrm{T}_{3}$ to suppress pituitary TSH secretion. Serum $\mathrm{T}_{4}$ concentrations were measured at weekly intervals, and TSH $\beta$ mRNA was measured in pituitaries obtained from WT and KO mice before and at the end of the 3-week period of $\mathrm{T}_{3}$ administration. WT mice exhibited a progressive decline in $\mathrm{T}_{4}$ concentrations throughout the treatment period; at the end of 3 weeks, the concentrations of $\mathrm{T}_{4}$ were undetectable (Figure 4c). In a similar fashion, TSH $\beta$ gene expression was completely obliterated by $\mathrm{T}_{3}$ administration in WT mice (Figure 4, a and b). In contrast, TR $\beta 2 \mathrm{KO}$ mice exhibited only partial suppression of $\mathrm{T}_{4}$, with easily measurable concentrations ( $>2 \mu \mathrm{g} / \mathrm{dL}$ ) after the 3 -week period of $\mathrm{T}_{3}$ treatment (Figure $4 \mathrm{c}$ ). There was also resistance at the level of the TSH $\beta$ gene, with KO mice revealing persistent TSH $\beta$ gene expression despite receiving 3 weeks of pharmacological $\mathrm{T}_{3}$ (Figure 4 , a and $\mathrm{b}$ ).

Impact on ligand-independent activation of the TSH $\beta$ gene in vivo. To assess the role of TR $\beta 2$ in mediating the activation of TSH $\beta$-subunit gene expression in the absence of thyroid hormone, mice were rendered hypothyroid by administration of $150 \mu \mathrm{Ci}$ of ${ }^{131}$. After 3 weeks, all mice exhibited $\mathrm{T}_{4}$ concentrations below the limit of detection of the $\mathrm{T}_{4}$ assay $(<0.5 \mu \mathrm{g} / \mathrm{dL})$. Pituitary RNA was obtained from hypothyroid WT and KO mice, and TSH $\beta$ expression was assessed by Northern blotting. TSH $\beta$ message was easily detected in $2.5,1.25$, and $0.625 \mu \mathrm{g}$ of total pituitary RNA. It is very difficult to detect TSH $\beta$ message in these small concentrations of total RNA in euthyroid mice (data not shown). Hence, there was clear induction of TSH $\beta$ message by hypothyroidism in both sets of mice. However, the abundance of TSH $\beta$ mRNA was 4-fold greater in WT mice than in KO mice at all concentrations of RNA examined (Figure 5, $a$ and b). Thus, in the absence of TR $\beta 2$, the degree of ligand-independent activation of the TSH $\beta$ gene is impaired in vivo.

Impact on GH gene expression. Given the expression of $\mathrm{TR} \beta 2$ in the somatotroph (28), and the positive regulation of $\mathrm{GH}$ by $\mathrm{T}_{3}$ (29), Northern blot analysis of $\mathrm{GH}$ gene expression was performed in control and $\mathrm{KO}$ mice at ambient $T_{4}$ levels and after 3 days of high-dose $T_{3}$ administration. TR $\beta 2 \mathrm{KO}$ mice exhibited a modest reduction $(\sim 30 \%)$ in $\mathrm{GH}$ gene expression. After $\mathrm{T}_{3}$ administration, GH expression increased by $60 \%$ in WT mice and by $30 \%$ in TR $\beta 2 \mathrm{KO}$ mice, suggesting reduced $\mathrm{T}_{3}$ responsiveness (Figure 6).

Effect on hearing. Given the profound impact of TR $\beta$ loss on hearing (25), we examined the ABRs in 8-weekold $\mathrm{KO}$ and WT mice. Surprisingly, TR $\beta 2 \mathrm{KO}$ mice did 
not exhibit any deficit in hearing at any of the frequencies tested. In fact, the ABR thresholds between WT and KO mice were overlapping (Figure 7). The 1 elevated threshold value, seen at the highest test frequency in $1 \mathrm{WT}$ mouse, presumably represents the onset of premature, age-related hearing loss, a progressive early onset hearing loss that has been well studied in the C57Bl6 strain (30).

\section{Discussion}

We have successfully inactivated the $\beta 2$ isoform of the TR. Our strategy was based on the fact that TR $\beta 1$ and $\mathrm{TR} \beta 2$ differ only in their $\mathrm{NH}_{2}$-termini and that these are encoded by distinct exons (5-7). The relative location of the exons encoding the TR $\beta 1$ and $\mathrm{TR} \beta 2 \mathrm{NH}_{2}$ termini are not known. It is also likely that in addition to alternate exon use, distinct promoters drive the expression of these $2 \mathrm{TR}$ isoforms $(6,31,32)$. It is clear from our data that disruption of the TR $\beta 2$-specific exon does not interfere with the splicing of the TR $\beta 1$ specific exons and the shared common exons. The selective targeting of TR $\beta 2$ also did not affect the spatial expression of the TR $\beta 1$ gene product. Although we did not examine the temporal expression of TR $\beta 1$ in this study, our data strongly suggest that the regulatory elements governing TR $\beta 1$ expression are not located within the TR $\beta 2$-specific exon, nor in the first $600 \mathrm{bp}$ of the adjacent intron that was also inactivated by our targeting strategy. This targeting strategy ensured that the entire coding sequence of the unique TR $\beta 2 \mathrm{NH}_{2}$ terminus was deleted. In fact, we were unable to detect by RT-PCR the existence of a truncated $\mathrm{NH}_{2}$-terminal fragment that could potentially act as a dominant inhibitor. Therefore, these mice enabled us to define the physiological role of TR $\beta 2$ in the regulation of the hypothalamic-pituitary-thyroid axis, and provided novel insight into differential roles of TR $\beta 1$ and TR $\beta 2$ in the regulation of auditory function.

The selective disruption of TR $\beta 2$ confirms the important role that this isoform plays in the regulation of the hypothalamic-pituitary-thyroid axis. The 2- to 3-fold increase in thyroid hormone concentration seen in mice lacking TR $\beta 2$ is similar to that reported in mice lacking the entire TR $\beta$ locus (21). The absolute hormone concentrations are not comparable, because our control values are lower than those reported by Forrest et al. (21). Nevertheless, it appears that the absence of $\operatorname{TR} \beta 2$ can account in large part for the hormonal abnormalities described in TR $\beta$-null mice. The residual TR $\beta 1$ is therefore unable to compensate for the absence of TR $\beta 2$. This may reflect qualitative differences in the ability of TR $\beta 1$ to mediate the negative regulation of TSH by thyroid hormone. This possibility is supported by a large body of in vitro data that suggest that TR $\beta 2$ is a more potent negative regulator of the TSH-subunit genes than is $\operatorname{TR} \beta 1(16,17)$. However, the lack of TR $\beta 2$ does not completely abrogate the responsiveness of the thyrotroph to thyroid hormone, as evidenced by the partial suppression of TSH $\beta$ mRNA after 3 weeks of $\mathrm{T}_{3}$
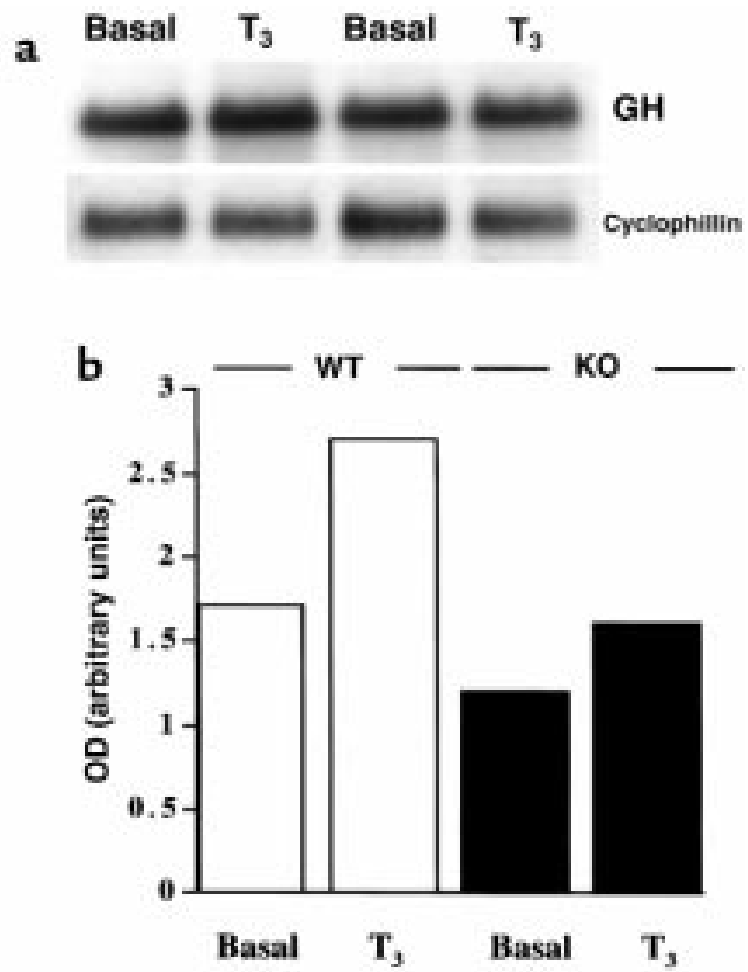

Figure 6

$\mathrm{GH}$ gene expression. (a) Representative Northern blot of total RNA obtained from pooled pituitaries for WT (first 2 lanes) and KO (last 2 lanes), demonstrating GH mRNA at ambient (basal) $\mathrm{T}_{4}$ concentrations and after administration of high doses of $\mathrm{T}_{3}$. Blots were also probed for cyclophillin. Five micrograms of RNA is loaded in each lane. Each lane represents RNA extracted from 3 pituitary glands. (b) Densitometry of $\mathrm{GH}$ mRNA abundance corrected for loading by hybridizing the same membranes with a cDNA for cyclophillin. Note the reduced basal GH expression and the blunted response to $T_{3}$.

treatment. The interpretation of the decline in $\mathrm{T}_{4}$ levels is more complex. The fall in $\mathrm{T}_{4}$ not only reflects impaired TSH suppression, but also reflects the ability of $\mathrm{T}_{3}$ to increase the peripheral clearance of $\mathrm{T}_{4}(33,34)$. This is one possible explanation for the similarity in the slopes of the decline in $\mathrm{T}_{4}$ in WT and TR $\beta 2$-null mice. The important difference, though, is the presence of measurable $\mathrm{T}_{4}$ in the TR $\beta 2$-null animals at a time when $\mathrm{T}_{4}$ levels are undetectable in WT mice. We believe that the persistence of $T_{4}$ in the TR $\beta 2$-null mice after $T_{3}$ treatment is due to persistence of TSH.

The partial suppression of TSH in response to $T_{3}$ administration suggests that the residual TR $\beta 1$ and TR $\alpha 1$ are capable of mediating $\mathrm{T}_{3}$-induced repression of the TSH-subunit genes. The recent reports of markedly elevated thyroid hormone concentrations in mice lacking both $\mathrm{TR} \alpha$ and $\mathrm{TR} \beta$ isoforms support this $(35,36)$. However, our data indicate that TR $\beta 2$ is required to mediate complete suppression of the axis by thyroid hormone. Whether or not TR $\beta 2$ alone can mediate all of the negative regulation of TSH production by thyroid hormone in vivo will only come from studies in mice with ablation of $\operatorname{TR} \beta 1$ and $\operatorname{TR} \alpha$, but 


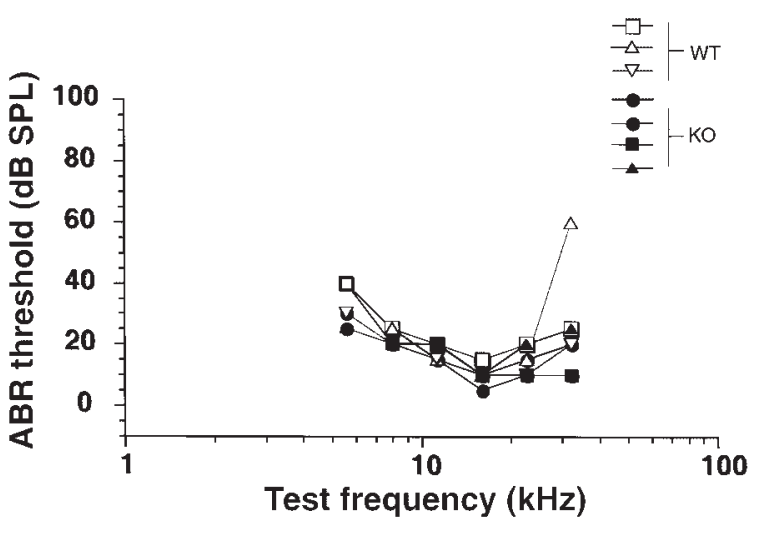

Figure 7

Evidence that cochlear function is normal in TR $\beta 2 \mathrm{KO}$ mice. ABRs in 8 -week-old KO $(n=4)$ and WT $(n=3)$ mice. Threshold SPLs $(0.0002$ $\left.\mathrm{dyn} / \mathrm{cm}^{2}\right)$ required for the detection of an $A B R$ were obtained across a range of test-tone frequencies. Note that at all frequencies tested, TR $\beta 2$ KO mice exhibit no abnormality in ABR thresholds.

with preserved expression of TR $\beta 2$. The demonstration that the central resistance to thyroid hormone occurring in TR $\beta 2 \mathrm{KO}$ mice is due in part to impaired downregulation of TSH $\beta$ gene expression by $\mathrm{T}_{3}$ does not preclude the possibility of impaired regulation at the level of the TRH neuron, given the expression of TR $\beta 2$ in the $\mathrm{T}_{3}$-responsive TRH neurons of the paraventricular hypothalamus (PVN) (9). Our model now provides an important resource with which to analyze the role of TR $\beta 2$ in the regulation of TRH expression in the PVN over a wide range of thyroid hormone concentrations.

An important new finding from this study is the demonstration in vivo that TR $\beta 2$ is a critical mediator of the ligand-independent activation of TSH $\beta$ gene expression. In transfection experiments, we demonstrated previously that TR $\beta 2$ is a much more potent mediator of ligand-independent activation of the TSHsubunit and TRH genes than either TR $\beta 1$ or TR $\alpha 1$ (17, $18,20)$. A potential mechanism for the differential activation capabilities of the TR isoforms on negatively regulated genes may reside in differential interactions with accessory proteins such as corepressors and coactivators. We have demonstrated previously that the ability of TR $\beta 2$ to mediate ligand-independent activation is independent of its interactions with $\mathrm{N}-\mathrm{CoR}(20)$. In contrast, $\mathrm{N}$-CoR binding limits the ligand-independent activation capability of TR $\beta 1$ and TR $\alpha 1$, and cotransfection of a potent dominant inhibitor of N-CoR converts these isoforms into strong mediators of ligandindependent activation (20). The molecular mediators of the ligand-independent activation of the TSH $\beta$ gene by TRs are currently unknown. It is likely that the enhanced potency of TR $\beta 2$ may reside in enhanced activation via its interaction with coactivator molecules.

Although our findings of impaired in vivo ligandindependent activation of the TSH $\beta$ gene strongly support earlier in vitro evidence that TR $\beta 2$ is the important mediator of ligand-independent activation, 2 additional possibilities warrant discussion. First, because TR $\beta 2$ is the most abundant TR isoform in the pituitary, loss of TR $\beta 2$ reduces the total number of pituitary TRs. Thus, the observed phenotype could simply represent the result of a net reduction in pituitary TR content. To ultimately prove that this defect is specific to the TR $\beta 2$ isoform, mice that selectively lack TR $\beta 1$ and TR $\alpha 1$ while retaining TR $\beta 2$ expression would need to be studied. If TR $\beta 2$ is the key mediator of ligand-independent activation of TSH $\beta$ in vivo, then such animals would be expected to exhibit no defects in the TSH response to hypothyroidism. Second, it could be argued that the impaired induction of TSH $\beta$ expression by hypothyroidism in the TR $\beta 2$-null mice may simply be due to the fact that basal TSH $\beta$ gene expression is already increased. We believe that this is unlikely because of our observations in transgenic mice with pituitary expression of a mutant TR transgene (37). Like the TR $\beta 2$-null mice, these animals exhibit pituitary resistance with a similar increase in basal TSH concentration. These animals increase their TSH concentrations 40 -fold above baseline in response to hypothyroidism, indicating that despite higher basal TSH levels, thyrotroph responsiveness is retained. It is of interest that these transgenic mice with pituitary expression of a mutant TR express $40 \%$ less TSH $\beta$ mRNA than controls with similar degrees of hypothyroidism, which contrasts with the $75 \%$ decrease observed in the TR $\beta 2 \mathrm{KO}$ mice. Thus, the impact of the absence of the receptor on ligand-independent activation in vivo is greater than that observed in the presence of a powerful dominant-negative mutant TR. These 2 independent lines of evidence indicate that ligand-independent activation of the TSH-subunit genes can be modulated in vivo by altering TR expression and function, and they provide compelling evidence that TRs mediate ligand-independent activation of the TSH $\beta$ gene in vivo.

Thyroid hormone has long been known to be a potent inducer of GH gene expression $(29,38,39)$. TR $\beta 2$ is expressed in the somatotroph (28), and there is evidence from studies in pituitary cell lines that TR $\beta 2$ is the major isoform mediating the stimulatory effect of thyroid hormone on GH gene expression (40). Furthermore, in the absence of thyroid hormone, TR $\beta 2$ exhibits potent ligand-independent activation of GH expression - in contrast to TR $\beta 1$, which mediates ligand-independent repression $(15,40)$. The TR $\beta 2$ KO mice therefore provided a unique model with which to evaluate the role of $\mathrm{TR} \beta 2$ in the regulation of $\mathrm{GH}$ gene expression by thyroid hormone in vivo. Interestingly, TR $\beta 2 \mathrm{KO}$ mice exhibited decreased basal GH expression and a blunted response to $T_{3}$. The small decrease in basal GH expression is very similar to the decrease in GH expression recently reported in mice lacking both TR $\beta$ isoforms (36). This raises the possibility that the changes in $\mathrm{GH}$ expression in TR $\beta$-null mice can be accounted for by loss of the TR $\beta 2$ isoform. It is important to note, however, that mice lacking both the TR $\alpha$ and TR $\beta$ isoforms exhibit profound 
downregulation of GH expression (36), indicating that TR $\alpha$ and TR $\beta$ isoforms are both important in GH regulation by thyroid hormone.

Thyroid hormone plays an important role in auditory function. TR $\alpha$ and TR $\beta$ are expressed in the developing ear; however, the expression of TR $\beta$ is restricted to the cochlea (10). Congenital hypothyroidism in humans is associated in many cases with deafness. In rodent models of congenital hypothyroidism, this is associated with structural abnormalities of the cochlea (41-43). Genetic syndromes associated with loss of TR $\beta$ also result in deafness, which was a striking characteristic of the initial patient described with resistance to thyroid hormone; this patient had a homozygous deletion of TR $\beta$ (44). More recently, Forrest et al. (21) have demonstrated that genetic deletion of the entire TR $\beta$ locus in mice results in variable amounts of hearing loss. On average, $\mathrm{ABR}$ thresholds in TR $\beta$-null mice were elevated by $20-40 \mathrm{~dB}$. In individual animals, however, the threshold elevations ranged from a few decibels to complete loss of auditory responsiveness (25). There were no gross structural cochlear abnormalities seen, implying that TR $\beta$ plays an important role in the maturation and maintenance of normal cochlear function but not in morphogenesis. Recent evidence suggests that the basis for the impaired hearing in TR $\beta$-null mice is a developmental delay in the expression of the fast-activating potassium conductance $\left(I_{\mathrm{K}, \mathrm{f}}\right)$ in inner hair cells (45). Bradley et al. (10) demonstrated coexpression of TR $\beta 1$ and TR $\beta 2$ in the developing cochlea in rats. Our mice, with selective deletion of the TR $\beta 2$ isoform of the TR, reveal that $\operatorname{TR} \beta 1$ is sufficient to mediate normal cochlear development and function. These observations highlight important isoform-specific differences in the regulation of hearing by TR $\beta$. Therefore, it will be important to determine whether the developmental regulation of $I_{\mathrm{K}, \mathrm{f}}$ is normal in TR $\beta 2$-null mice.

The lack of an impact of TR $\beta 2$ deletion on hearing stands in contrast to its important role in the pituitary. The precise molecular mechanisms by which TRs regulate the development of hearing are unknown. As the target genes for the TR are identified in the cochlea, important insights into the factors governing the isoform-specific differences in gene regulation are likely to be obtained. A potential reason for the differential effects may lie in differences in the relative expression and relative roles of accessory cofactors in the ear versus the pituitary. It is known that retinoid receptors are expressed within the developing ear and are important heterodimer partners with the TRs on positively regulated genes (46). We have previously shown that TR $\beta 1$ and TR $\beta 2$ exhibit distinct functional interaction with RXRs and N-CoR $(19,20)$. On negative TREs, the transcriptional activity of TR $\beta 1$ can be modified by liganded RXR, whereas that of TR $\beta 2$ cannot (19). We have also shown that ligand-independent activation by TR $\beta 1$ and TR $\alpha 1$ is masked by corepressors, whereas the ligand-independent activation by TR $\beta 2$ is not (20). Hence, tissue-specific differences in the expression and distribution of accessory cofactors may partly explain the differential roles of these TR isoforms in tissues in which they are coexpressed.

In summary, these studies have demonstrated that in keeping with its restricted expression, TR $\beta 2$ plays a central role in the regulation of the hypothalamic-pituitarythyroid axis, and some role in the regulation of $\mathrm{GH}$. In the thyrotroph, the function of TR $\beta 2$ cannot be replaced by the other TR isoforms. In the auditory system, however, normal hearing develops in the absence of TR $\beta 2$.

\section{Acknowledgments}

This work was supported by National Institutes of Health (NIH) grants DK-02485 (to E.D. Abel), DC00188 (to M.C. Liberman), and DK-49126 and DK50564 (to F. Wondisford). E.D. Abel was the recipient of a Faculty Development Award from the Robert Wood Johnson Foundation; the Eleanor and Mile's Shore 50th Anniversary Scholars in Medicine Fellowship (Harvard Medical School); and a Thyroid Research Advisory Council Award. E.G. Moura and C.C. PazosMoura were recipients of a CNPq grant from the government of Brazil. H. Kaulbach was supported by NIH training grant T32 DK-07561. possibilities. Endocr. Rev. 14:184-193.

2. Sap, J., et al. 1986. The $c$-erb-A protein is a high affinity receptor for thyroid hormone. Nature. 324:635-640.

3. Weinberger, C., et al. 1986. The c-erb-A gene encodes a thyroid hormone receptor. Nature. 324:641-646.

4. Hodin, R.A., et al. 1989. Identification of a thyroid hormone receptor that is pituitary specific. Science. 244:76-79.

5. Wood, W.M., Ocran, K.W., Gordon, D.F., and Ridgway, E.C. 1991. Isolation and characterization of mouse complementary DNAs encoding alpha and beta thyroid hormone receptors from thyrotrope cells: the mouse pituitary-specific $\beta 2$ isoform differs at the amino terminus from the corresponding species from rat pituitary tumor cells. Mol. Endocrinol. 5:1049-1061.

6. Wood, W.M., et al. 1994. Structural and functional characterization of the genomic locus encoding the murine beta 2 thyroid hormone receptor. Mol. Endocrinol. 8:1605-1617.

7. Sakurai, A., Nakai, A., and DeGroot, L.J. 1990. Structural analysis of human thyroid hormone receptor beta gene. Mol. Cell. Endocrinol. 71:83-91.

8. Cook, C.B., Kakucska, I., Lechan, R.M., and Koenig, R.J. 1992. Expression of thyroid hormone receptor $\beta 2$ in rat hypothalamus. Endocrinology. 130:1077-1079.

9. Lechan, R.M., Yanping, Q., Jackson, I., and Mahdavi, V. 1994. Identification of thyroid hormone receptor isoforms in thyrotropin-releasing hormone neurons of the hypothalamic paraventricular nucleus. Endocrinology. 135:92-100.

10. Bradley, D.J., Towle, H.C., and Young, W.S. 1994. Alpha and beta thyroid hormone receptor (TR) gene expression during auditory neurogenesis: evidence for TR isoform-specific transcriptional regulation in vivo. Proc. Natl. Acad. Sci. USA. 91:439-443.

11. Schwartz, H.L., Lazar, M.A., and Oppenheimer, J.H. 1994. Widespread distribution of immunoreactive thyroid hormone beta 2 receptor (TR beta 2) in the nuclei of extrapituitary rat tissues. J. Biol. Chem. 269:24777-24782

12. Hodin, R.A., Lazar, M.A., and Chin, W.W. 1990. Differential and tissuespecific regulation of the multiple rat c-erbA messenger RNA species by thyroid hormone. J. Clin. Invest. 85:101-105.

13. Jones, K.E., and Chin, W.W. 1991. Differential regulation of thyroid hormone receptor messenger ribonucleic acid levels by thyrotropin-releasing hormone. Endocrinology. 128:1763-1768.

14. Lazar, M.A. 1990. Sodium butyrate selectively alters thyroid hormone receptor gene expression in GH3 cells. J. Biol. Chem. 265:17474-17477.

15. Sjoberg, M., and Vennstrom, B. 1995. Ligand-dependent and -independent transactivation by thyroid hormone receptor beta 2 is determined by the structure of the hormone response element. Mol. Cell. Biol. 15:4718-4726.

16. Ng, L., Forrest, D., Haugen, B.R., Wood, W.M., and Curran, T. 1995. Nterminal variants of thyroid hormone receptor $\beta$ : differential function 
and contribution to the syndrome of resistance to thyroid hormone. Mol. Endocrinol. 9:1202-1213.

17. Safer, J.D., et al. 1997. Isoform variable action among thyroid hormone receptor mutants provides insight into pituitary resistance to thyroid hormone. Mol. Endocrinol. 11:16-26

18. Langlois, M.-F., et al. 1997. A unique role of the $\beta-2$ thyroid hormone receptor isoform in negative regulation by thyroid hormone. J. Biol. Chem. 272:24927-24933.

19. Cohen, O., Flynn, T.R., and Wondisford, F.E. 1995. Ligand-dependent antagonism by retinoid $\mathrm{X}$ receptors of inhibitory thyroid hormone response elements. J. Biol. Chem. 270:13899-13905.

20. Hollenberg, A.N., Monden, T., Madura, J.P., Lee, K., and Wondisford, F.E. 1996. Function of nuclear co-repressor protein on thyroid hormone response elements is regulated by the receptor A/B domain. J. Biol. Chem. 271:28516-28520.

21. Forrest, D., et al. 1996. Recessive resistance to thyroid hormone in mice lacking thyroid hormone receptor beta: evidence for tissue-specific modulation of receptor function. EMBO J. 15:3006-3015.

22. Fraichard, A., et al. 1997. The T3R alpha gene encoding a thyroid hormone receptor is essential for post-natal development and thyroid hormone production. EMBO J. 16:4412-4420.

23. Wikstrom, L., et al. 1998. Abnormal heart rate and body temperature in mice lacking thyroid hormone receptor $\alpha 1$. EMBOJ. 17:455-461.

24. Weiss, R.E., et al. 1997. Thyrotropin regulation by thyroid hormone in thyroid hormone receptor $\beta$-deficient mice. Endocrinology. 138:3624-3629.

25. Forrest, D., Erway, L.C., Ng, L., Altschuler, R., and Curran, T. 1996. Thyroid hormone receptor $\beta$ is essential for development of auditory function. Nat. Genet. 13:354-357.

26. Li, E., Bestor, T.H., and Jaenisch, R. 1992. Targeted mutation of the DNA methyltransferase gene results in embryonic lethality. Cell. 69:915-926.

27. Papaioannou, V., and Johnson, R. 1993. Production of chimeras and genetically defined offspring from targeted ES cells. In Gene targeting: a practical approach. A.L. Joyner, editor. Oxford University Press. Oxford, United Kingdom 107-146.

28. Childs, G.V., Taub, K., Jones, K.E., and Chin, W.W. 1991. Triiodothyronine receptor beta-2 messenger ribonucleic acid expression by somatotropes and thyrotropes: effect of propylthiouracil-induced hypothyroidism in rats . Endocrinology. 129:2767-2773.

29. Wood, D.F., et al. 1987. The effect of thyroid hormones on growth hormone gene expression in vivo in rats. J. Endocrinol. 112:459-463.

30. Li, H.S., and Borg, E. 1991. Age-related hearing loss of auditory sensitivity in two mouse genotypes. Acta Otolaryngol. (Stockh.) 111:827-834

31. Sakurai, A., Miyamoto, T., and DeGroot, L.J. 1992. Cloning and characterization of the human thyroid hormone receptor beta 1 gene promoter. Biochem. Biophys. Res. Commun. 185:78-84.

32. Suzuki, S., Miyamoto, T., Opsahl, A., Sakurai, A., and DeGroot, L.J. 1994.
Two thyroid hormone response elements are present in the promoter of human thyroid hormone receptor beta 1. Mol. Endocrinol. 8:305-314.

33. Cullen, M.J., Doherty, G.F., and Ingbar, S.H. 1973. The effect of hypothyroidism and thyrotoxicosis on thyroxine metabolism in the rat. Endocrinology. 92:1028-1033.

34. Kaplan, M.M., and Utiger, R.D. 1978. Iodothyronine metabolism in liver and kidney homogenates from hyperthyroid and hypothyroid rats. Endocrinology. 103:156-161.

35. Gauthier, K., et al. 1999. Different functions for the thyroid hormone receptors TRalpha and TRbeta in the control of thyroid hormone production and post-natal development. EMBOJ. 18:623-631.

36. Gothe, S., et al. 1999. Mice devoid of all known thyroid hormone receptors are viable but exhibit disorders of the pituitary-thyroid axis, growth, and bone maturation. Genes Dev. 13:1329-1341.

37. Abel, E.D., et al. 1999. Novel insight from transgenic mice into thyroid hormone resistance and the regulation of thyrotropin. J. Clin. Invest. 103:271-279.

38. Martial, J.A., Seeburg, P.H., Guenzi, D., Goodman, H.M., and Baxter, J.D. 1977. Regulation of growth hormone gene expression: synergistic effects of thyroid and glucocorticoid hormones. Proc. Natl. Acad. Sci. USA. 74:4293-4295.

39. Mirell, C.J., et al. 1987. Influence of thyroidal status on pituitary content of thyrotropin beta- and alpha-subunit, growth hormone, and prolactin messenger ribonucleic acids. Mol. Endocrinol. 1:408-412.

40. Ball, S.G., Ikeda, M., and Chin, W.W. 1997. Deletion of the thyroid hormone beta1 receptor increases basal and triiodothyronine-induced growth hormone messenger ribonucleic acid in GH3 cells. Endocrinology. 138:3125-3132.

41. Deol, M.S. 1973. An experimental approach to the understanding and treatment of hereditary syndromes with congenital deafness and hypothyroidism. J. Med. Genet. 10:235-242.

42. Hebert, R., Langlois, J.-M., and Dussault, J.H. 1985. Permanent defects in rat peripheral auditory function following perinatal hypothyroidism: determination of a critical period. Brain Res. 23:161-170.

43. Uziel, A. 1986. Periods of sensitivity to thyroid hormone during the development of the organ of corti. Acta Otolaryngol. (Stockh.) 429:23-27.

44. Refetoff, S., DeWind, L.T., and DeGroot, L.J. 1967. Familial syndrome combining deaf-mutism, stippled epiphyses, goiter and abnormally high PBI: possible target organ refractoriness to thyroid hormone. J. Clin. Endocrinol. Metab. 27:279-294.

45. Rusch, A., Erway, L.C., Oliver, D., Vennstrom, B., and Forrest, D. 1998. Thyroid hormone receptor beta-dependent expression of a potassium conductance in inner hair cells at the onset of hearing. Proc. Natl. Acad. Sci. USA. 95:15758-15762.

46. Corey, D.P., and Breakefield, X.O. 1994.Transcription factors in inner ear development. Proc. Natl. Acad. Sci. USA. 91:433-436. 